\title{
Technological Neutrality: Recalibrating Copyright in the Information Age
}

Carys J. Craig

Osgoode Hall Law School of York University, ccraig@osgoode.yorku.ca

Follow this and additional works at: http:// digitalcommons.osgoode.yorku.ca/olsrps

Part of the Intellectual Property Law Commons

\section{Recommended Citation}

Craig, Carys J., "Technological Neutrality: Recalibrating Copyright in the Information Age" (2017). Osgoode Legal Studies Research Paper Series. 186.

http://digitalcommons.osgoode.yorku.ca/olsrps/186 


\section{OSGOODE HALL LAW SCHOOL \\ LEGAL STUDIES RESEARCH PAPER SERIES}

Research Paper No. 5

Volume 13, Issue 1, 2017

\section{Technological Neutrality: Recalibrating Copyright in the Information Age}

Theoretical Issues in Law, Vol. 17(2), 2016.

\section{Carys J. Craig}

Further information and a collection of publications from the Osgoode Hall Law School Legal Studies Research Paper Series can be found at:

http://www.ssrn.com/link/Osgoode-Hall-LEG.html

\section{Editors:}

Editor-in-Chief: Carys J. Craig (Associate Dean of Research \& Institutional Relations and Associate Professor, Osgoode Hall Law School, York University, Toronto)

Production Editor: Antonnia Kiana Blake (Osgoode Hall Law School, York University, Toronto) 
Osgoode Legal Studies Research Paper No. 5

Vol. 13/ Issue. 1/ (2017)

\title{
Technological Neutrality: Recalibrating Copyright in the Information Age
}

Theoretical Issues in Law, Vol. 17(2), 2016.

\author{
Carys J. Craig
}

\begin{abstract}
: foster as technologies evolve.

\section{Keywords:}

Author(s):

Carys J. Craig

Osgoode Hall Law School, York University

E: ccraig@osgoode.yorku.ca
\end{abstract}

This Article aims to draw the connection between how we conceptualize legal rights over information resources and our capacity to develop technologically neutral legal norms in the information age. More specifically, it identifies and critically examines three competing approaches to the idea of technological neutrality apparent in copyright jurisprudence. Ultimately, it is argued that true technological neutrality requires not simply the seamless expansion of legal rights into new technological contexts, but the careful, contextual recalibration of rights and interests in light of shifting values and changing circumstances. As a normative principle, technological neutrality in copyright law thus demands a nuanced and relational understanding of the rights at play, and the social values that they seek to 


\title{
Technological Neutrality: Recalibrating Copyright in the Information Age
}

\begin{abstract}
Carys J. Craig*
This Article aims to draw the connection between how we conceptualize legal rights over information resources and our capacity to develop technologically neutral legal norms in the information age. More specifically, it identifies and critically examines three competing approaches to the idea of technological neutrality apparent in copyright jurisprudence. Ultimately, it is argued that true technological neutrality requires not simply the seamless expansion of legal rights into new technological contexts, but the careful, contextual recalibration of rights and interests in light of shifting values and changing circumstances. As a normative principle, technological neutrality in copyright law thus demands a nuanced and relational understanding of the rights at play, and the social values that they seek to foster as technologies evolve.
\end{abstract}

\section{INTRODUCTION}

If this is, indeed, the "information era" in which we find ourselves, then the power to own, control, and access information is surely the power that will define our era and determine our future. Just as control over the means of

* $\quad$ LL.B. $\left(1^{\text {st }}\right.$ Cl. Hons), LL.M., S.J.D., Associate Dean (Research \& Institutional Relations), Associate Professor, Osgoode Hall Law School, York University, Toronto. An earlier version of this Article was presented at the Constitution of Information conference, held at the University of Toronto in May 2015. My thanks to Lisa Austin and Ariel Katz for organizing this ambitious conference, and to all of the participants (including, in particular, Frank Pasquale, Julie Cohen, Brett Frishmann and Michael Geist) for their helpful comments. I am also grateful to Joseph Cuygenkeng, Thomas Felix and Yidan Ding for their research assistance. 
production shaped the emergence and evolution of industrial might, so too must control over information determine the dynamics of postindustrial power. The law, which ascribes rights and protects privileges in relation to valuable resources, plays a key role in both allocating power and controlling its flow. In the information era, the law has continued to play its traditional role in granting rights and regulating behavior in relation to valuable resources but increasingly the resource is information itself. The idea of a constitution of information evokes a particular vision of legal rights held by individuals over information — including rights over the intangible works in which information is found. The focus of this Article is on the law's allocation of rights over information resources through the particular vehicle of copyright law. Specifically, it is concerned with how the law's allocation and enforcement of copyright responds (or refuses to respond) to technological change - and to the shifting dynamics of information, creativity and communication that such change entails.

There is nothing new about the fundamental nature of "information" or the simple fact of its creation and exchange that sets this so-called information era apart from its predecessors. The nature of our relationship to the creative works in which information is found, however, has always been informed by the technologies available for capturing and sharing these works. Thus it was the development of the printing press that precipitated the emergence of rules governing the printing of literary works; and it was the proliferation of affordable printing technologies that provoked into existence the modern copyright system.

In the past quarter century or so, the "digital shift" and the emergence and rapid proliferation of network technologies has again dramatically changed how we capture and share creative works, thereby altering in perceptible ways the value of information and its significance in our lived experiences. ${ }^{1}$ The laws that have governed ownership over such informational "things" for hundreds of years have correspondingly swelled in importance to become a central component (and core determinant) of our information ecosystem. We should ask ourselves whether they merit this prominence ${ }^{2}$ : are our copyright laws capable of appropriately allocating rights and protecting privileges in the information era, or are they playing a role in the allocation of power that could never have been anticipated - and cannot, now, be satisfactorily justified?

It is with this question in mind that I hope to advance, in these pages, a fairly modest claim: if copyright's centrality in our evolving information

\footnotetext{
1 Cf. Niva Elkin-Horen, Tailoring Copyright to Social Production, 12 THEORETICAL INQUIRIES L. 309, 321 (2011).

$2 C f$. Jessica Litman, Digital Copyright (2d ed. 2006).
} 
ecosystem is to be justified, copyright law must at least be capable of adapting to the changing realities of information - changes in its flow, its value, and its role in human (economic, cultural and social) relations - that are the inevitable result of technological development. Copyright law must therefore be capable of changing with technology.

This assertion may seem on its face to be at odds with the widely-touted principle of "technological neutrality," according to which laws should be developed to be independent of any particular technology. Rather than changing in response to specific technological developments, goes the logic, our laws should rise above such reactivity to ensure the consistency and sustainability of regulations over time and across technologies. Seen in this way, the objective of our lawmakers should be to transcend the vagaries of technological innovation for the sake of both regulatory efficiency and, in a larger sense, the rule of law itself. ${ }^{3}$ To the contrary, I suggest, an appropriate understanding of technological neutrality necessitates active responsiveness to changing technologies. As a principled approach to copyright law, true technological neutrality should stand in stark contrast to what we might call "technology blindness." ${ }^{4}$ Copyright laws that are essentially blind to the differences between old and new technologies can create massive inequalities between technologies, and their objectively "neutral" application will produce very different results over time. We should know by now that ostensibly neutral legal norms can render important differences invisible, and thereby fail to produce substantive equality between the differently situated. In copyright law, I argue, substantive equality between technologies requires shifting and adjusting the allocation, nature and scope of rights in order to consistently pursue the goals of copyright through the choppy currents of technological change. What is needed, in other words, is not technology blindness but a continuous process of "equilibrium adjustment" as technologies evolve. ${ }^{5}$ Real technological neutrality sustains a normative equilibrium in the face of change.

3 See Bert-Japp Koops, Should ICT Regulation Be Technology-Neutral?, in Starting Points for ICt Regulation: Deconstructing Prevalent Policy OneLINERS 77 (Bert-Jaap Koops, Miriam Lips, Corien Prins \& Maurice Schellekens eds., 2006). Rule of law considerations feature largely in what Koops identifies as Category C: the broad category of usage of "technological neutrality" related to "legislative technique."

4 Cf. Ian Hosein \& Alberto Escudero Pascual, Understanding Traffic Data and Deconstructing Technology-Neutral Regulations 8 (Working Paper, 2002), http://www.it46.se/docs/papers/unece-latest-escuderoa-hoseini.pdf(“Attempts to be technology-neutral should be interrogated, lest in our blindness we reduce democratic protections and oversight under the deterministic veil of progress."). $C f$. Orin Kerr, An Equilibrium-Adjustment Theory of the Fourth Amendment, 
By casting technological neutrality in these terms, this Article seeks to draw a connection between our conceptualization of rights over information and our capacity to develop technologically neutral legal norms in the information age. Ultimately, it warns that the more individualistic and rigid our vision of legal rights, the less technologically neutral our regulation of information is likely to be. I suggest that, in order to achieve the kind of technological neutrality that best serves the public purposes of copyright, we need to take a contextual and relational approach to the rights at play.

The Article proceeds as follows. Part I explores competing conceptions of technological neutrality and endorses what I call the "expansive" vision of technological neutrality, which situates copyright disputes over new technologies in the context of the overarching purposes of the copyright system. This discussion is built primarily on an analysis of Canada's recent Supreme Court copyright jurisprudence on the meaning and role of technological neutrality. Part II explores various difficulties associated with traditional rights-based reasoning in the copyright context, showing how it supports a restrictive and unsatisfactory approach to technological neutrality. It then sketches out a "relational" theory of copyright law and suggests the advantages of this approach in actively responding to new technologies. The Article concludes that an authors' rights-based approach to copyright obstructs rather than facilitates the development of a technologically neutral copyright law, to the detriment of the copyright system and, more broadly, our information ecosystem. Fundamentally, the capacity to develop and apply law in a manner responsive to changing technological realities requires a purposive approach to structuring the legal relationships between people, information and technology.

\section{Conceptual Approaches to Technological Neutrality}

\section{A. Introducing Technological Neutrality}

As it is commonly understood, the principle of technological neutrality prescribes that laws can and should be developed in such a way that they are independent

125 Harv. L. REv. 426 (2011) (describing how changing technology and social practice can destabilize the balance of police power of traditional Fourth Amendment rules, and suggesting that courts might respond to these new facts by adjusting legal rules to restore the preexisting balance of police power - a response Kerr calls "equilibrium adjustment"). In similar terms, I see technological neutrality as requiring "a case-by-case reassessment of preexisting law in light of present-day realities" in order "to restore the status quo" of the copyright balance. Id. at 492 . 
of any particular technology, neither favoring nor discriminating against specific technologies as they emerge and evolve. Perhaps because technologically neutral laws hold the promise of sustainability in a time of rapid technological change, the principle is regularly invoked as an uncontested regulatory starting point. ${ }^{6}$ While the general wisdom seems to be that technological neutrality is, like "motherhood and apple pie," an unquestionably good thing, Chris Reed has rightly cautioned that "this consensus among legislators seems to have developed in an almost complete absence of any clear understanding [of] what the term 'technology neutrality' might actually mean."7 Similarly, Brad Greenberg has recently observed that technological neutrality is "undertheorized and, thereby, poorly understood. While scholars frequently refer vaguely to the principle, few have conceptualized it, and legislators have accepted it without critical inquiry."

In fact, technological neutrality has many shades of meaning, and, of course, different meanings can produce differing applications with more or less desirable results. In this Part, drawing on a fuller analysis that I have presented elsewhere, ${ }^{9}$ I identify what I perceive to be three different approaches to conceptualizing technological neutrality in the copyright context, all of which are discernable in the jurisprudence both in Canada and internationally. I sketch out these approaches in broad terms, and then argue that the third approach - the "expansive" interpretation - should be preferred. It avoids the shortcomings of the more restrictive approaches and holds the key to maintaining a normatively justifiable copyright system over time.

At the outset, however, I should acknowledge that actual technological neutrality is not, in my view, an attainable state for copyright law; it is more akin to a normative quest. I doubt it can truthfully be said of any law that it is "technologically neutral," at least as an objectively verifiable claim without caveat. Neutrality itself is illusive - a myth too often invoked to obscure the realities of inequality, self-interest or political agenda - and the principle of technological neutrality is no different. As such, the three versions of the principle to which we now turn are best understood as interpretive tools, which have been and may be deployed in the task of applying copyright law

$6 \quad$ Koops, supra note 3, at 77-78.

7 Chris Reed, Taking Sides on Technology Neutrality, 4 SCRIPT-ED 263, 265 (2007).

8 Brad A. Greenberg, Rethinking Technology Neutrality, 100 Minn. L. Rev. 1495, 1498 (2016).

9 See Carys J. Craig, Technological Neutrality: (Pre)Serving the Purposes of Copyright Law, in The Copyright Pentalogy: How the Supreme Court of Canada Shook the Foundations of Canadian Copyright Law 271 (Michael Geist ed., 2013). 
in new technological circumstances. ${ }^{10}$ None can produce a law that transcends technological realities; each offers a route by which to reason about how the law ought to apply. (And each, of course, has the potential to serve specific interests, and advance particular agendas.)

\section{B. Three Approaches to Technological Neutrality}

I argue that there are essentially three conceptual approaches to technological neutrality, which I have labelled the restrictive, intermediate and expansive approaches. With these labels, I mean to describe the scope of the principle as understood: what it is that we can see, and what we focus on, when we look at copyright law through the lens of technological neutrality. A restrictive approach to technological neutrality takes the narrowest view, zooming in to focus on the words of the statute and the technical activities at issue. With this lens, we can simply seek to apply the law as written to the new technological activity. The intermediate approach broadens its focus, pulling out the metaphorical lens a little in order to capture a wider frame: with this lens, we can see not just the activity but the end result of the activity, or the function it performs. We can then seek to apply the law in a "functionally equivalent" way; that is, applying it equally to new technologies having the same function or effect as older technologies. Finally, the expansive approach pulls out still further, until it captures within its wide-angle frame not only the specific activity and its function or effect, but also where this activity fits within the broader context of the copyright system and its purposes. With an expansive understanding of technological neutrality, then, we can seek to apply the law to new technologies in a purposive manner that consistently advances the normative goals of copyright. Without getting mired in the technical details of particular cases, this Section identifies and describes these competing conceptions and articulations of technological neutrality as found in the Canadian jurisprudence. ${ }^{11}$

\section{i. The Restrictive Approach: Formal Nondiscrimination}

The first approach to technological neutrality in copyright law is what I call the "restrictive approach": it has a narrow focus on the words of the statute and the specific technological activities undertaken by the defendant. Its purpose is to ensure that copyright applies to all technologies, even those unforeseen

10 I am indebted to Julie Cohen for this characterization of the three approaches to technological neutrality that I describe as, essentially, interpretive tools.

11 For a more detailed description and analysis of the facts and ratios in each of the key Canadian cases, see Craig, supra note 9. 
technologies that could not have been within the contemplation of the legislative drafters. While broad in its potential reach, the approach is restrictive insofar as it is concerned only with the extension of copyright's exclusive rights to new technologies notwithstanding the differences between the new and old. It is aimed at ensuring the continued capacity of rights-holders to control and exploit protected works on new platforms and in new media. When regarded as such, the concept is effectively synonymous with "media neutrality," and finds its grounding, in the Canadian context, in the copyright owner's right of reproduction "in any material form." " An unauthorized reproduction, whether made by copying by hand, by photocopier, camera or computer, triggers the reproduction right for copyright purposes. ${ }^{13}$ The approach is "means-oriented" in the sense that it is concerned with the application of law to new technical means for using and exploiting protected works. Taking this approach, one is likely to adopt what Brad Greenberg calls the "internal perspective": looking inside a machine or process to identify infringing activities rather than focusing on the outputs of technological processes. ${ }^{14}$

In the Canadian jurisprudence, the basic expression of this restrictive approach to technological neutrality is found in the dissenting judgment of Justice Rothstein in Entertainment Software Association (ESA) v. Society of Composers, Authors and Music Publishers of Canada ${ }^{15}$ : "Media neutrality means that the Copyright Act should continue to apply in different media, including more technologically advanced ones." 16 This statement reflects a narrow vision of technological neutrality as concerned only with nondiscrimination between technological means in a formalistic sense: the law remains equally applicable across different technologies. The emphasis is not on the effect of the law as such, or the effects of technological change, but on the law's extension to new contexts. Thus, the author of a newspaper article can control its reproduction in an electronic database, and the copyright owner in a

12 See Gregory R. Hagen, Technological Neutrality in Canadian Copyright Law, in The Copyright Pentalogy, supra note 9, at 307, 314-15.

$13 C f$. Brad Greenberg, Aereo and the Spirit of Technology Neutrality, CONCURRING OpINIONS, http://concurringopinions.com/archives/2014/06/aereo-and-the-spiritof-technology-neutrality.html (last visited 29 Apr., 2015).

14 Greenberg, supra note 8, at 1537.

15 Entm't Software Ass'n (ESA) v. Soc'y of Composers, Authors and Music Publishers of Can., [2012] S.C.C. 34 (Can.) (concluding that the download of a videogame containing a musical work constituted a "communication by telecommunication" of that work for which compensation was due).

$16 I d$. 121. Justice Rothstein was quoting from the majority ruling in Robertson $v$. Thomson Corp., [2006] S.C.C. 43 ๆ 49 (Lebel \& Fish JJ. writing for Bastarache, LeBel, Deschamps, Fish \& Rothstein JJ.) (Can.). 
musical work should be recompensed when a copy is transmitted online. ${ }^{17}$ The underlying assumption is that the legal rights recognized in respect of the old technology must be equally worthy of recognition and protection in the new technological setting.

To the extent that broader policy concerns are considered in this restrictive neutrality analysis, the concern tends to be with the continued recognition and protection of authors' or owners' rights as technologies change, with a view to ensuring the owner's continued ability to exploit the work, even in new ways and in unforeseen markets. This is clear in the dictum endorsed by Justice Rothstein, who continues: "Media neutrality is not a license to override the rights of authors - it exists to protect the rights of authors and others as technology evolves." 18 The restrictive approach thus tends to be invoked (or at least implicitly at play) when finding infringement by users of new media.

In keeping with this approach, in the recent case of Canadian Broadcasting Corp. v. SODRAC 2003 Inc., ${ }^{19}$ Justice Rothstein, now writing for the majority, emphasized that the principle of technological neutrality, though "central to Canadian copyright law, .. . cannot change the express terms of the Copyright Act." ${ }^{20}$ The case involved "broadcast-incidental" digital copies of works made to facilitate licensed broadcasting. The Court held that such copies were reproductions like any other, and so engaged the reproduction right as would any non-exempted copy, based simply on the plain language of the statute. Differences between broadcast-incidental copying practices in analog and digital contexts would not justify treating digital copies differently: seen through the restrictive lens, then, the law as written simply extends into the new technological context, treating a copy as a copy.

\section{ii. The Intermediate Approach: Functional Equivalence}

What I have called the "intermediate approach" to technological neutrality gives a broader significance to the concept. It is concerned not simply with equal treatment of rights across technologies, but with achieving similar outcomes for functionally equivalent technological processes. Whereas the restrictive version of the principle demands only that "the Copyright Act should continue to apply in different media," 21 an intermediate approach such

17 Robertson, [2006] S.C.C.; Entm't Software Ass'n (ESA), [2012] S.C.C. (Rothenstein, LeBel, Fish and Cromwell JJ., dissenting).

18 Id. $₫ 49$.

19 Can. Broad. Corp. (CBC) v. SODRAC 2003, Inc., [2015] S.C.C. 57 (Can.).

20 Id. 1 51; see Gregory Hagen, Interpreting the Right of Reproduction in SODRAC, INTELL. PROP. J. (forthcoming 2016) (arguing that this ruling reflected an unduly restrictive approach to the role of principle in statutory interpretation).

21 Robertson, [2006] S.C.C. at 49. 
as that adopted by the Supreme Court of Canada in Society of Composers, Authors and Music Publishers of Canada v. Bell Canada aims to ensure that the law is applied "in a way that operates consistently" across different media, "regardless of the form of media involved, or its technological sophistication.".22 The emphasis is not on formal nondiscrimination between technologies, but rather on achieving substantive equivalence of effect when the law is applied across different technologies. In this case, the Court declined to assess the "amount" of the use in a fair dealing analysis based on the aggregate number of music samples streamed to consumers because to do so would disadvantage digital dealings, thereby undermining the goal of technological neutrality. The formulation offered by Justice Abella and accepted by the full bench in the Bell case thus suggests a more functional and effects-oriented approach to technological neutrality, ensuring that no effective disadvantage is suffered by those who make use of new technological means. ${ }^{23}$

Because it is effects-oriented, the perspective adopted for the intermediate approach is typically "external" in focus: looking to what the technology accomplishes rather than the technical processes involved in producing the outcome. Another way to think of this is to view the technology as a "black box" whose internal contents are invisible: what matters to the decisionmaker is what goes in, and what comes out. The external perspective, then, "looks only at the technological output — at what, not how," 24 and thus avoids many of the pitfalls of technical specificity (not the least of which is technical complexity beyond the ken of the average lawyer or judge). Thus, in Rogers v. SOCAN, the Supreme Court treated on-demand streaming as a performance in public, analogous to traditional broadcasting, notwithstanding the technical differences between "push" and "pull" technologies: "If the nature of the activity in both cases is the same, albeit accomplished through different technical means, there is no justification for distinguishing between the two for copyright purposes. ${ }^{25}$

22 Soc'y of Composers, Authors \& Music Publishers of Can. v. Bell Can. [2012] S.C.C. $36 \uparrow 43$ (Can.).

23 In Bell, the Court expressed concern that, for the purposes of conducting a fair dealing analysis, assessing the "amount" of dealing in light of the aggregate amount of uses would lead to disproportionate findings of unfairness in respect of dealings with digital as opposed to non-digital works. Such an interpretation, it was said, would undermine the goal of technological neutrality in copyright law. Id.

24 Greenberg, supra note 8, at 1537 (citing Orin S. Kerr, The Problem of Perspective in Internet Law, 91 GEo. L.J. 357, 357 (2003)).

25 Rogers Communications, Inc. v. Soc'y of Composers, Authors and Music Publishers of Can., [2012] S.C.C. 35 || 29 (Rothstein J.). 
The intermediate approach differs from the restrictive approach to the extent that it engages with policy considerations beyond merely the reach of copyright protection. As the Bell case demonstrates, the intermediate approach, in its quest for functional equivalence, looks not only to the extension of owners' rights but also justifies the extension of users' rights (in the form of defenses and exceptions to infringement ${ }^{26}$ ) to achieve a technologically neutral result. In this way, it offers, at least potentially, a far more nuanced analysis of what technological neutrality ought to entail in particular circumstances.

Because the goal is to achieve substantively equivalent results across different media, fairness to all parties means not disadvantaging users for employing new or more sophisticated technologies to achieve equivalent ends. This permits, at least notionally, the possibility of different treatment for substantively different technologies in order to ensure an equivalent result. Whereas, for example, traditional broadcasting techniques required the making of only a few incidental copies, the vastly inflated number of reproductions involved in digital broadcasting may necessitate different treatment of those copies. So, having held that broadcast-incidental digital copies trigger the reproduction right, the Court in $C B C$ proceeded to apply the principle of technological neutrality to the valuation of the royalties payable in respect of such copies. This aspect of the majority reasons adopts what is arguably an intermediate approach, in the sense that it focuses on the outcome or effect of the use (albeit in value-based terms) and seeks to ensure that commensurate legal obligations attach to an act of equivalent (economic) effect: "[I]n the valuation of a right, technological neutrality requires that different technologies using reproductions of copyright protected work that produce the same value to the users should be treated the same way." ${ }^{27}$

26 See CCH Canadian Ltd. v. Law Soc'y of Upper Can., [2004] S.C.C. 13, [2004] 1 S.C.R. 339 (Can.) (the Supreme Court of Canada first declaring that "exceptions to copyright infringement" were "more properly understood as users' rights") (emphasis added).

27 Can. Broad. Corp. (CBC) v. SODRAC 2003, Inc., [2015] S.C.C. 57 9 72. The passage continues: "Conversely, different technologies using reproductions that produce different values should not be treated the same way. ... Technological neutrality requires that the Board compare the value derived from the use of reproduction in the two technologies in its valuation analysis." Id. ๆ 72 . Respectfully, the majority erred, in my view, by relegating consideration of technological neutrality to the valuation of royalties. The vehicle of tariff-setting involves a market-driven assessment of the value of licensed copies, while technological neutrality should guide the analysis of whether such copies need to be licensed at all. 
The intermediate and restrictive approaches to technological neutrality can produce very different - sometimes contradictory — conclusions about the appropriate application of copyright doctrine in particular cases. The intermediate approach avoids some, but not all, of the limitations inherent in the restrictive approach to technological neutrality. Rather than simply protecting rights across different or previously unanticipated media, it seeks to avoid discriminating between functionally equivalent technologies. The analysis is therefore geared towards achieving substantively equal treatment of new technologies, at least where a functionally equivalent process previously existed: activities with equivalent outcomes receive similar legal treatment.

Cast in these terms, however, the analysis remains rooted in the specific activity in question and its immediate effect. Where it is possible to say that one activity is functionally equivalent to another, this provides a shortcut to a technology-neutral conclusion. ${ }^{28}$ But it is not always possible to compare one analog activity to a digital one, and not all technological advances proceed in so linear or parallel a fashion. The reliance upon technological analogy is often unhelpful, being capable of producing conflicting but equally credible arguments that lead inexorably to incompatible conclusions. The recent case of American Broadcasting Co. v. Aereo, Inc. affords a good example. ${ }^{29}$ Reliance upon technological analogy permitted the ultimately successful argument that the one-to-one transmission of a digitized signal was sufficiently "cable-like" to constitute public performance and attract liability in the same way as would a cable transmission. A conflicting but compelling technological analogy was available to support the argument that the defendant's digital time-shifting service was functionally equivalent, if technically superior, to the traditional VCR, and should thus be treated similarly in law (i.e., as a means of carrying out a personal, non-infringing use). ${ }^{30}$ The competing but apt analogies in this case merely begged the question.

The choice of analogy may, then, have the unfortunate effect of appearing to require a particular conclusion, when really the desired conclusion requires a particular choice of analogy. Worse still, use of analogy to compare activities across technologies is often misleading, causing the decision-maker to overlook differences and fail to perceive the larger paradigm shifts that occur through the

28 See Deborah S. Tussey, Technology Matters: The Courts, Media Neutrality, and New Technologies, 12 J. Intell. Prop. L. 427, 479 (2005).

29 Am. Broad. Co. v. Aereo, Inc., 134 S. Ct. 2498 (2014).

30 Brief Amici Curiae of Law Professors and Scholars in Support of Respondents, at 22-23, Am. Broad. Co., 134 S. Ct., http://isp.yale.edu/sites/default/files/ American\%20Broadcasting\%20Companies\%20v.\%20Aereo.pdf (citing Sony Corp. of Am. v. Universal City Studios, Inc., 464 U.S. 417 (1984)). 
iterative process of technological advancement. ${ }^{31}$ By contrast, the "expansive" approach to technological neutrality is less concerned with finding analogous processes or equivalent effects in particular instances, and more concerned with finding an appropriate resolution in light of changing technological realities and overarching policy concerns.

\section{iii. The Expansive Approach: Prescriptive Parallelism}

The expansive approach to technological neutrality operates as a guiding principle that informs the application of copyright law to new technologies: fundamentally, the principle is one of "prescriptive parallelism," meaning that the balance of rights traditionally sought in copyright law should be preserved in new technological environments. ${ }^{32}$ What must remain equal in respect of new technology, then, is not the treatment of particular, potentially analogous, activities as such. Rather, what must be consistent across technologies is the application of core copyright concepts and doctrine in a manner that appropriately balances the rights and interests at stake - maintaining, in the face of technical change, the steady pursuit of copyright's policy goals. It therefore requires doctrinal adaptability as the copyright balance is continually recalibrated in response to new developments. The expansive approach to technological neutrality as a guiding principle is neither primarily means- nor effects-oriented, but purpose-oriented. It supports substantive nondiscrimination between functional equivalents, writ large: it seeks outcomes to copyright cases that preserve the balance of rights in the digital realm. In this sense, technological neutrality operates as a framing principle, demanding a purposive or teleological application of old laws to new situations. Moreover, it necessitates not willful technology-blindness, but a clear-sighted recognition of the disruptive force and political significance of technological change.

This expansive vision of technological neutrality is also discernable in Canada's Supreme Court jurisprudence. In Robertson, which concerned the electronic archiving of newspaper articles, the minority described the electronic database as functionally equivalent to a library collection of printed

31 If, for example, the writing of fan fiction has been fundamentally transformed by the establishment of online communities for sharing and peer review, analogizing fan-ficcing to the offline activities of reading groups or writing clubs risks missing the point. See Betsy Rosenblatt \& Rebecca Tushnet, Transformative Works: Young Women's Voices on Fandom and Fair Use, in EGirLs, ECitizens 385, 388 (Jane Bailey \& Valerie Steeves eds., 2015).

32 Jerome H. Reichman, Graeme B. Dinwoodie \& P. Samuelson, A Reverse Notice and Takedown Regime to Enable Public Interest Uses of Technically Protected Copyrighted Works, 22 Berkeley TECH L.J. 981 (2007). 
newspapers. ${ }^{33}$ Beyond such analogies, however, the dissenting judgment articulated a principled commitment both to the purposes of copyright law and to the promise of new technologies:

The Copyright Act was designed to keep pace with technological developments to foster intellectual, artistic and cultural creativity. In applying the Copyright Act to a realm that includes the Internet and the databases at issue in this case, ... the public benefits of this digital universe should be kept prominently in view. As Professor Michael Geist observes: "The Internet and new technologies have unleashed a remarkable array of new creativity, empowering millions of individuals to do more than just consume our culture, instead enabling them to actively and meaningfully participate in it." ${ }^{34}$

This broad vision supported the conclusion that the newspaper could lawfully reproduce print editions in the searchable electronic database, allowing the benefits of digitization to flow more freely. The expansive approach to technological neutrality reemerged in the majority reasons of Justices Abella and Moldaver in $E S A$, which analogized digital to traditional means of transferring copies of works, describing the internet delivery of digital copies as akin to a "technological taxi." 35 The risks of reliance on analogy were apparent when Justice Rothstein in dissent pointedly remarked that taxis "need not give free rides." ${ }^{" 36}$ But the expansive approach to technological neutrality that informed the majority judgment was not reducible to the identification and like treatment of functional equivalents. Rather, the majority's analysis built on the broader assertion that " $[\mathrm{t}]$ he traditional balance between authors and users should be preserved in the digital environment." ${ }^{\prime 37}$

33 Robertson v. Thomson Corp., [2006] S.C.C. 43 ฯ 88-90 (Abella J., writing for McLachlin C.J. \& Binnie, Abella \& Charron JJ.) (Can.) ("This is simply the electronic analogy to stacking print editions of a newspaper on a shelf.").

34 Id. 79 (citing Michael Geist, Our Own Creative Land: Cultural Monopoly \& The Trouble with Copyright 9, Lecture Given at Hart House Committee, Toronto, Can. (Mar. 7, 2006), http://cdn.michaelgeist.ca/wp-content/uploads/2006/05/ hhl06_Online_Book.pdf).

35 Entm't Software Ass'n (ESA) v. Soc'y of Composers, Authors and Music Publishers of Can., [2012] S.C.C. 34 ๆ 5 (Can.).

$36 I d$. 150 . The majority judgment drew a less vulnerable analogy when it compared downloading to a store clerk putting a copy of the work in the hands of the end user.

37 Id. ๆף 7-8 (citing Carys Craig, Locking Out Lawful Users: Fair Dealing and Anti-Circumvention in Bill C-32, in From 'Radical Extremism' to 'Balanced Copyright’: Canadian Copyright and the Digital Agenda 177 (Michael Geist ed., 2010)). 
With this purpose in mind, the majority found that technological neutrality meant avoiding the imposition of "an additional layer of protections ... based solely on the method of delivery of the work to the end user." ${ }^{38}$ Imposing "gratuitous costs" 39 on the use of new and more efficient technologies would upset the copyright balance in the digital environment, contrary to the principle of technological neutrality. Rather than simply extending the communication right to cover the online transmission, technological neutrality meant refusing to extend copyright liability onto new "technologies and activities that, while theoretically capable of being included under the [Copyright] Act, only incidentally implicate copyright." ${ }^{40}$ The Court's expansive vision of technological neutrality thus allowed it to limit the scope of the right to avoid disadvantaging users of new technologies and thereby obstructing the larger goals of the copyright system.

It is unfortunate, in my view, that the majority approach in $E S A$ became the minority approach in the recent $C B C$ case, in which Justice Abella's dissenting reasons exemplified the expansive version of technological neutrality as I have described it. Faced with the question of whether digital broadcast-incidental copies should be treated as reproductions for copyright purposes, Justice Abella situated it in the context of copyright's purpose:

The question in this case, once again, is how to preserve [the balance that best supports the public interest in creative works] in the face of new technologies that are transforming the mechanisms through which creative works are produced, reproduced and distributed. . . The answer to this challenge, in my view, lies in applying a robust vision of technological neutrality as a core principle of statutory interpretation under the Copyright Act. ${ }^{41}$

The robust vision that Justice Abella propounds combines media neutrality (protecting "the rights of users [as well as owners] of copyrighted material across new media"42) with functional equivalence ("focus[ing] on the essential character of the activity and not the technical modalities by which it is achieved"43) in the context of copyright's purpose ("to protect the fine balance between users

\footnotetext{
$38 \quad I d .9121$.

39 Id. $ๆ 9$.

40 See Cameron Hutchinson, Technological Neutrality Explained (\& Applied to CBC v. SODRAC) (Working Paper, 2014), http://ssrn.com/abstract=2533734.

41 Can. Broad. Corp. (CBC) v. SODRAC 2003, Inc., [2015] S.C.C. 57 9 147-148 (Can.).

42 Id. $ๆ 151$.

43 Id. 164.
} 
and creators, between access and reward, enshrined in the Copyright Act." ${ }^{\prime 4}$ ) The dissenting reasons strive for substantive nondiscrimination between functional equivalents, looking at external outcomes and effects rather than internal processes, and taking a purposive interpretation of the statute that "seeks to preserve the accepted balance between creators and users in the digital environment." ${ }^{45}$ With this expansive vision of what technological neutrality entails, the minority concludes:

The essential character of the broadcasting activity does not change with the adoption of modern digital technologies that are dependent on the creation of incidental copies in order to accomplish the activity. Each broadcast-incidental copy is not a separate reproduction of the work under the Act simply because the technical imperatives of effecting a broadcast require the presence of multiple copies. They do not, as a result, attract separate royalties. To conclude otherwise is to doom both technological neutrality and the ability of copyright law to preserve the delicate balance between the rights of copyright holders and the public's interest in the dissemination of creative works. ${ }^{46}$

\section{Interim Conclusion: Technological Neutrality and the Principled Approach}

To summarize, the expansive approach to technological neutrality recognizes, as a guiding principle, that the interpretation of copyright law in new technological contexts should maintain the appropriate balance of rights in furtherance of copyright's purposes. It is much broader in its vision than is the restrictive proposition that copyright should, subject to the express terms of the statute, extend to cover previously unknown technical means and processes. It is also much more ambitious and flexible than the intermediate claim that copyright should simply treat functionally equivalent actions in a similar way. Tasked with conducting copyright's "equilibrium adjustment," it therefore requires a reassessment of the law in light of present-day technological realities in order to preserve or restore the copyright balance.

Now it might be argued that the conclusion I offer is no conclusion at all. Is the expansive version so vague in its assertions that any application of law might equally claim the badge of "technological neutrality"? As with legal principles generally, it is true that technological neutrality in this sense

\footnotetext{
$44 \quad I d .9157$.

45 Id. $\uparrow 181$.

46 Id. $\uparrow 164$.
} 
does not dictate a particular answer to a particular legal question. ${ }^{47}$ It does, however, relieve us of the obsessive internal examination of technological processes, which is, from a policy perspective, hardly worthwhile; and it allows us to escape intractable debates about which analogies most aptly apply to describe new technology-enabled activities. Simply put, it reminds us of the question we should be asking: given the new realities of the current technological environment, what rights should we recognize - and subject to what limits - if we aim to advance the objectives of the copyright system? It is the search for this answer that should guide the application of the law in respect of new technologies. ${ }^{48}$

Greenberg identifies several fundamental problems associated with the principle of technological neutrality in his well-reasoned argument against neutrality and in favor of technological discrimination. Central among them is the following claim:

Technology neutrality discounts, if not overlooks countervailing reasons to avoid future-proofing and the downsides to treating differences alike. Significantly, technology neutrality assumes the appropriateness of old laws regulating new technologies. Yet fading normativity and elusive neutrality ... make technology neutrality both suboptimal and self-defeating. ${ }^{49}$

The problems identified by Greenberg speak accurately to the difficulties associated with the restrictive and, to a significant degree, intermediate approaches to technological neutrality as I have attempted to describe them..$^{50}$

47 At least, it does not do so for any decision-maker bar Dworkin's Hercules. Hutchinson, supra note 40, describes technological neutrality as a legal principle in the sense most famously explicated by Ronald Dworkin. Dworkin's imaginary "Hercules" is an ideal judge capable of finding, through the application of legal rules and principles, the "right" answer to any legal problem. See Ronald Dworkin, TAKing Rights SERIOUSLy 75, 105 (1978).

48 A common criticism of the concept of technological neutrality as employed in Entm't Software Ass'n (ESA) v. Soc'y of Composers, Authors and Music Publishers of Can., [2012] S.C.C. 34 (Can.), is that it provides no practical guidance on future rulings. See Can. Broad. Co. v. SODRAC 2003 Inc., 2014 F.C.A. 84, 118 C.P.R. 79 (4th) (Can.). However, viewed as a legal principle, or simply as an interpretative tool, the criticism is overstated. That it does not produce a particular practical solution to a specific legal problem is not an appropriate basis on which to dismiss a guiding principle as unhelpful.

49 Greenberg, supra note 8, at 1522-23.

50 Greenberg identifies four core problems: Prediction (legislators cannot know whether and to what extent current laws should regulate new and unpredictable 
Thus, for example, the simple "ex ante application of the law to new technologies" that is envisioned in the restrictive approach wrongly "assumes that subjecting extant and future technologies to copyright liability imposes the same costs and benefits to the copyright system and to society." ${ }^{\prime 1}$ Neither the intermediate nor the expansive versions of technological neutrality, however, should permit one to "overlook the possibility that different technologies warrant different treatment, [thereby] mistaking equal application for equivalence." ${ }^{52}$ To the extent that a narrow approach to technological neutrality may, as Greenberg argues, fail to account for new technological uses that "disrupt the policies Congress previously balanced," 53 avoiding such disruption to the policy balance is precisely the point of the expansive approach. Moreover, there is no "pretense" of value-neutrality in the expansive approach. At its core lies the recognition that our copyright law reflects a particular understanding of the value of rewarding authors and encouraging creativity and dissemination of works. It directs attention to these normative assumptions rather than obscuring them, paving the way for a more open and fruitful debate about which norms should apply.

The problems that Greenberg rightly identifies do not, then, necessitate the abandonment of technological neutrality in its expansive conception, nor undermine its principled significance. Technological neutrality in the expansive sense permits (indeed demands) that the law recognize, respond and adapt (sometimes in technologically specific ways) to new and disruptive or paradigmshifting technologies, rather than holding fast to previous legal constructs and reasoning by analogy. In my view, however, to abandon technological neutrality as an overarching principle would be to abandon the powerful notion that we must recalibrate copyright's balance to new technological circumstances, and maintain normative vigilance as conditions change. Copyright requires this expansive vision of technological neutrality in order to appropriately adapt to technological change: only through constant recalibration and equilibrium adjustment can the law maintain the necessary balance of rights and interests to advance its purpose, and retain its legitimacy, in the digital age.

technologies); Penumbra (the penumbra of doubt produced by technological change creates growing uncertainly in the law); Perspective (confusion about whether to adopt an internal or external perspective when analyzing new technological processes produces conflicting results); and Pretense (technological neutrality is not in fact neutral, and the pretense of neutrality obscures discrimination against new technologies). Id. at 1498.

51 Id. at 1523.

52 Id.

53 Id. at 1499. 
There is, however, a significant obstacle to this approach deeply embedded in our traditional copyright model, and it is to this that we now turn. The obstacle to which I refer is the common deontological commitment to copyright as primarily an author's right; when the author's right appears rigid and unchanging in the face of technological change, it inevitably limits copyright's capacity to respond to new realities in a teleological way. Part II explores this connection between competing conceptions of the author's right and competing approaches to technological neutrality.

\section{RECONCEPTUALIZING (COPY)RIGHT}

\section{A. Technological Neutrality and Rights-Based Rhetoric}

My suggestion is that the restrictive approach to technological neutrality, as described above, is bound up with the rigid adherence to the idea of the author's right to "own" his or her work. I have argued elsewhere that this commitment to authorial entitlement is ill-founded from a theoretical perspective, misunderstands the nature of authorship and expression, and unnecessarily stifles the cultural dialogue. ${ }^{54}$ My purpose here is more limited: I mean only to suggest, in this Section, that the rights-based approach to copyright anchors a restrictive version of technological neutrality. As such, it has the power to preclude the expansive approach to technological neutrality and to obstruct the pursuit of copyright's purposes in the digital era. In the following Section, I propose a relational account of copyright that is more conducive to the kind of contextual analysis contemplated by the expansive approach.

Before we proceed to look closely at the theory of copyright that best supports technological neutrality, however, it is important to identify in specific terms the way in which rights-based rhetoric and the value judgments about ownership claims are tied up in cases that tackle new technologies.

\section{i. Authors'Rights and the Restrictive Approach to Technological Neutrality} We have already seen, in the descriptions of competing approaches to technological neutrality, statements that reveal the values informing each approach. Specifically, we might begin by recalling the statement that informed both the majority ruling in Robertson and the dissent in ESA, propounding a limited role for technological neutrality, restrictively construed: "Media neutrality is not a licence to override the rights of authors - it exists to protect

54 See Carys J. Craig, Copyright, Communication and Culture: Towards a Relational Theory of Copyright LaW (2011). 
the rights of authors and others as technology evolves." ${ }^{55}$ The primary focus was on protecting the rights of authors (and presumably other owners) in respect of the new technology. ${ }^{56}$ Media neutrality in this restrictive approach can only support, but cannot override, the extension of these ownership rights into new technological contexts. The majority's technological neutrality analysis in $C B C$ was similarly constructed around the right-holder's entitlement to be justly compensated for use of the right, and the assumption that any value gained by the use of more efficient technology should flow back to the right-holder. ${ }^{57}$

The British case of $T V$ Catchup provides another interesting example. While not explicitly invoking the concept of media or technology neutrality, the facts of the case directly put in issue the question of whether and how old laws should constrain the exploitation of new markets made possible by new technologies. The defendant in the case offered a service that permitted its users to receive, via the internet, live streams of free-to-air television broadcasts that they were legally entitled to watch. When referred to the European Court of Justice, the Court approached the question with the following sentiment front of mind:

First of all, it is to be noted that the principal objective of [the Directive] is to establish a high level of protection of authors, allowing them to obtain an appropriate reward for the use of their works, including on the occasion of communication to the public. It follows that "communication to the public" must be interpreted broadly .... ${ }^{58}$

It proceeded to rule that "each transmission or retransmission of a work which uses a specific technical means must, as a rule, be individually authorised by the author of the work in question." ${ }^{59}$ This was notwithstanding a previous ruling that "a mere technical means to ensure or improve reception of the

55 Entm't Software Ass'n (ESA) v. Soc'y of Composers, Authors and Music Publishers of Can., [2012] S.C.C. 34 \ 49 (Can.) (Lebel \& Fish JJ.) (cited by Rothstein J. \121).

56 For an interesting discussion on this theme, see Stewart E. Sterk, Rhetoric and Reality in Copyright Law, 94 Mich. L. Rev. 1197, 1198, 1239 (1996).

57 Can. Broad. Corp. (CBC) v. SODRAC 2003, Inc., [2015] S.C.C. 57 q 70, 79 (Can.).

58 Case C-607/11, on request from the High Court of England and Wales in the matter of ITV et al. v. TV Catchup Ltd. 2013 E.C.R. I-1 920 (citing Directive 2001/29/EC on the Harmonisation of Certain Aspects of Copyright and Related Rights in the Information Society [2001] OJ L167/12) (emphasis added); $c f$. Case C-325/14, SBS Belgium NV v. Belgische Vereniging van Auteurs, Componisten en Uitgevers (SABAM), [2015] WLR (D) 466 ๆ 20.

59 TV Catchup, 2013 E.C.R \ 24. 
original transmission within [an authorized] catchment area does not constitute a "communication." 60 The Court reasoned that this limitation did not extend to cover a new transmission by improved means. Having prioritized the protection of the owner's broad communication right, the Court paid little heed to arguments about the consumer interest in receiving the content to which they were entitled on a superior technical platform. ${ }^{61}$ The exclusive power to exploit the superior technical capability was reserved for the incumbent rightsholder in a manner that reflects a restrictive understanding of technological neutrality. ${ }^{62}$

The Australian case of National Rugby League Investments Pty Limited v. Singtel Optus Pty Ltd. ${ }^{63}$ raised a similar legal question about the lawfulness of a cloud storage personal recording service. Optus relied on an exception for private and domestic recording, which would permit, for example, the video-recording of the same content for later viewing. ${ }^{64}$ The lower court, which accepted this argument, began its reasons by noting that "copyright legislation has had to balance the legitimate interests of the makers of original works and of ordinary citizens who use technological advances to copy those works for their own use in their private or domestic lives." 65 Focusing on balancing the various competing interests at play, and emphasizing the extent to which "daily life of persons in Australia and many other countries has transformed over the last 20 years with advances in technology," 66 the court

60 Id. $\uparrow 28$ (citing Football Ass'n Premier League v. QC Leisure, 2011 E.C.R. I-9083 194).

61 It held that "the intervention of such a technical means must be limited to maintaining or improving the quality of the reception of a pre-existing transmission and cannot be used for any other transmission." The technical intervention here was considered to be a "different" transmission and so not permissible improvement. Id. ๆๆ 28-29.

62 Lord Floyd of the English High Court subsequently determined that some of the transmissions, though implicating the communication right, benefitted from a cable retransmission defence under section 73 of the United Kingdom's Copyright Designs and Patents Act 1988 c-48 (Order dated 7 October 2013). On appeal, the English Court of Appeal made a further reference to the Court of Justice regarding the permissible scope of the section 73 defence. [2015] EWCA Civ 204.

63 Nat'l Rugby League Inv. Pty Ltd. v. Singtel Optus Pty Ltd., [2012] F.C.A.F.C. 59 (Austl.).

64 Copyright Act 1968, (Cth), s. 111 (Austl.).

65 Singtel Optus Pty Ltd. v. Nat'l Rugby League Inv. Pty Ltd. (No. 2), [2012] F.C.A. 34 ๆ8 (Austl.) (emphasis added).

66 Id. ๆ 60. 
extended the exception on the basis that the service offered is substantively no different from a VCR or DVR. The ruling was guided by an expansive vision of technological neutrality. Overturning this decision on appeal, the Full Court took a narrow approach, reasoning that the consumer was not solely responsible for making the copy, and giving short shrift to the significance of technological neutrality as a guide to statutory interpretation of exceptions:

We are conscious that the construction which we are satisfied the language of s 111 requires is one that is capable of excluding, and does in fact in this instance exclude, a later technological development in copying. However, no principle of technological neutrality can overcome what is the clear and limited legislative purpose of s 111. It is not for this Court to re-draft this provision to secure an assumed legislative desire for such neutrality . . . . ${ }^{67}$

In the U.S. Aereo case, the majority similarly suggested that the extension of copyright exceptions to new technologies is the task of the legislature: "[T]o the extent commercial actors or other interested entities may be concerned with the relationship between the development and use of such technologies and the Copyright Act, they are of course free to seek action from Congress. ${ }^{968} \mathrm{In}$ the absence of such action, the Court emphasized the presumed Congressional intent to "protect a copyright holder from the unlicensed activities of Aereo as from those of cable companies." ${ }^{99}$ Even in his dissenting reasons, Justice Scalia conceded, "I share the Court's evident feeling that what Aereo is doing (or enabling to be done) to the Networks' copyrighted programming ought not to be allowed." 70

These cases, and the way in which the rights and baseline expectations of rights-holders are framed, all indicate, in one sense or another, a default assumption that technological neutrality ought only to posit the extension of an owner's exclusive rights onto new technological means of exploiting protected works and ensure just reward for such uses. Where an analysis of functional equivalence threatens to support the extension of user rights or otherwise to limit the owner's rights in respect of exploiting the new technology,

67 Nat'l Rugby League, [2012] F.C.A.F.C. at $9 \uparrow$ 96-99. The judgment continues: "In the present matter such are the conflicting interests and values, such are the possible consequential considerations of which account might need to be taken that, if a choice is to be made to extend or otherwise modify an exception such as $\mathrm{s} 111$, this requires a legislative choice to be made, not a judicial one."

68 Am. Broad. Co. v. Aereo, Inc., 134 S. Ct. 2498, 17 (2014).

$69 I d$. at 13.

70 Id. at 12. 
the courts consistently retreat to the position that such limits require explicit action by the legislature.

The implication, once again, is that copyright is primarily concerned with the protection of authors and owners; limits and exceptions must be explicit and clearly defined in respect of each new technological possibility, failing which authors' rights should continue to reach seamlessly across disruptive technologies. This tacit assumption finds its more forthright expression in the Brief of Amicus Curiae Ralph Oman, Former Register of Copyrights of the United States:

Whenever possible, when the law is ambiguous or silent on the issue at bar, the courts should let those who want to market new technologies carry the burden of persuasion that a new exception to the broad rights enacted by Congress should be established. That is especially so if that technology poses grave dangers to the exclusive rights that Congress has given copyright owners. Commercial exploiters of new technologies should be required to convince Congress to sanction a new delivery system and/or exempt it from copyright liability. That is what Congress intended..$^{71}$

This argument makes explicit the unarticulated assumptions that often inform a restrictive vision of technological neutrality. Oman begins by noting: "There can be no serious dispute as to whether rights under the Copyright Act are broad, subject only to specific, narrow limitations enacted by Congress and that new developments in technology are not supposed to be able to truncate those rights." 72 Seen in this light, the role of technological neutrality is precisely to preserve strong authors' rights in the face of technological change:

Congress drafted the Copyright Act to prevent the creative efforts of authors from being usurped by new technologies. That core principle is at the heart of the Copyright Act. Congressional intent would be

71 Brief of Amicus Curiae Ralph Oman, Former Register of Copyrights of the United States, Aereo, Inc., 134 S. Ct. at 17, http://jstyre.com/misc/Oman Amicus_20120921.pdf. For critical commentary on this Brief, see Kevin Smith, Coming Clean on Technical Neutrality, Duke Univ. LiBrary (Oct. 23, 2012), http:// blogs.library.duke.edu/scholcomm/2012/10/23/coming-clean-on-technologicalneutrality/; and Mike Masnick, Former Copyright Boss: New Technology Should Be Presumed Illegal Until Congress Says Otherwise, Techdirt (Sept. 27, 2012), https://www.techdirt.com/blog/innovation/articles/20120927/00320920527/ former-copyright-boss-new-technology-should-be-presumed-illegal-untilcongress-says-otherwise.shtml.

72 Brief of Amicus Curiae Ralph Oman, supra note 71. 
undercut by any decision that would sanction the use of technologies which could be used indirectly to undermine its goals. ${ }^{73}$

While these words did not find their way into the written reasons of the Court, the Aereo ruling does reflect a similar impulse to safeguard the rights of copyright owners against the disruptive potential of new technological uses and users - and similarly fails to perceive any equal and opposite need to safeguard users' rights as technology evolves. In my view, this is technological neutrality in its most restrictive - and least satisfactory - form. Far from preserving the balance of copyright, it loads up only one side of the balance with the weight to withstand technological change. The other side of the balance is left entirely vulnerable to the vicissitudes of technology and its exploitation. This is the flaw entailed by the traditional rights-based approach to copyright, which prioritizes above all else the protection of the author's right in new technological contexts.

\section{ii. Balancing Rights and the Public Interest: Expanding Technological Neutrality}

The cases in which technological neutrality is given a more expansive reading, and a more central role in guiding statutory interpretation, reveal a very different framing rhetoric that focuses on both the promise of new technologies, and the balance or public interest purposes at the core of copyright.

We have already seen the dissenting Justices in the Canadian Robertson case lauding the potential of digital technologies to benefit the public and further the purposes of copyright law. ${ }^{74}$ Notably, their analysis began with a description of the overarching purposes of copyright as "promoting the public interest in the encouragement and dissemination of artistic and intellectual works, and justly rewarding the creator of the work." 75 Having emphasized the public interest in accessing archived newspapers and enjoying the "benefits of this digital universe," this framing principle justified limiting the authors' rights to control reproduction of their works. ${ }^{76}$

73 Id.

74 See supra note 16 and accompanying text.

75 Robertson v. Thomson Corp., [2006] S.C.C. 43 q 469 (Can.) (citing, inter alia, Théberge v. Galerie d'Art du Petit Champlain Inc., [2002] 2 S.C.R. 336, 2002 S.C.C. 34, 30 (Can.); CCH Can. Ltd. v. Law Soc'y of Upper Can., [2004] 1 S.C.R. 339, 2004 S.C.C. 13, $\ 23$ (Can.); and Soc'y of Composers, Authors and Music Publishers of Can. (SOCAN) v. Can. Ass'n of Internet Providers, [2004] 2 S.C.R. 427, 2004 S.C.C. 45 ๆ 40 (Can.)).

76 Robertson, [2006] S.C.C. $\uparrow 70$. 
The majority ruling in ESA similarly emphasized the centrality of balance in copyright, and the need to limit owners' rights: ESA's argument that the communication right was not implicated by online delivery of copies was "consistent with this Court's caution in [Théberge], that the balance in copyright between promoting the public interest in the encouragement and dissemination of works and obtaining a just reward for the creator requires recognizing the 'limited nature' of creators' rights." 77 The analysis of the minority in $C B C$, which concluded that incidental copies did not implicate the reproduction right, also began with recognition of copyright's "careful balance" and a warning that "tilting the balance too far towards protection of creators' rights would undermine the right of users to access and work with creative materials." 78 From this perspective, the additional value or economic gains created for users by virtue of new technologies was seen to "have nothing to do with the copyright holder's legitimate interests," "79 giving rise to no additional entitlement for the right-holder.

A similar connection between a concern with copyright's public interest purposes and the more expansive version of technological neutrality reveals itself in other cases beyond Canada, where courts made room for new actors to offer new technology-enabled services to consumers. In its ruling in Football Association Premier League v. QC Leisure, for example, the European Court of Justice wrote, with regard to the transient copying exception in Article 5(1) of the Information Society Directive, that it "must allow and ensure the development and operation of new technologies and safeguard a fair balance between the rights and interests of right holders, on the one hand, and of users of protected works who wish to avail themselves of those new technologies, on the other." ${ }^{80}$ With this concept of balance to the fore, it ruled that acts of reproduction performed within the memory of a satellite decoder and on a television screen fall within the exception and can therefore be carried out without the authorization of the copyright holders concerned.

In RecordTV v. Mediacorp TV, ${ }^{81}$ Singapore's Court of Appeal held that an "internet digital video recorder" for free-over-the-air content "did not

77 Entm't Software Ass'n (ESA) v. Soc'y of Composers, Authors and Music Publishers of Can., [2012] S.C.C. 34, 7 (Abella \& Moldaver JJ.) (Can.) (emphasis added).

78 Can. Broad. Corp. (CBC) v. SODRAC 2003, Inc., [2015] S.C.C. 57 q 145-147 (Can.).

79 Id. $\uparrow 182$.

80 C-403/08, Football Ass'n Premier League Ltd. v. QC Leisure and C-429/08, Karen Murphy v. Media Protection Serv. Ltd. \ 164 (joined cases) (citing Directive 2001/29/EC, supra note 58).

81 RecordTV Pte Ltd. v. MediaCorp TV Singapore Pte Ltd., [2010] S.G.C.A. 43 (Sing.). 
communicate" the plaintiff's broadcasts to the public and was non-infringing. The Singapore Court framed its doctrinal analysis in the following purposive terms:

In our view, where the Copyright Act is unclear as to how much copyright protection ought to be granted to a copyright owner, the courts should not be quick to construe a statutory provision so liberally as to deter or restrict technological innovations by preventing them from being applied in a manner which would benefit the public without harming the rights of the copyright owner. . . .

[T] he present appeal requires us to balance the competing interests of several stakeholders (viz, consumers, content providers as well as technology and service vendors) in a manner which would result in the most benefits to and impose the least costs on society as a whole. ${ }^{82}$

Emerging from these judgments, I believe, is a simple but illuminating idea: the more committed a decision maker is to protecting authors' rights as the primary purpose of copyright law, the more content she will be with a restrictive approach to technological neutrality; correspondingly, the more committed a decision maker is to the notion that the core principle of copyright is balancing author and user rights for the benefit of society as a whole, the more expansive her vision of technological neutrality becomes. With this idea in mind, my goal, in the next Section, is to suggest why traditional rights-based reasoning obstructs the path to substantive technological neutrality - and to briefly sketch an alternative relational approach that could better pave the way for copyright's future. It is not possible here, of course, to provide a full account of what a relational approach to copyright might mean. ${ }^{83} \mathrm{I}$ do hope, however, to at least join the dots between a more relational understanding of copyright and the expansive vision of a technology-neutral copyright system.

\section{B. Relational Rights and the Evolving Role of Copyright Law}

In the liberal constitutional tradition, the language of rights has evolved to capture the notion that there are certain basic rights that no government can violate ${ }^{84}$ Fundamental to this notion is the idea that these rights are immutable

82 Id. 9 67-68.

83 I have begun to more fully explore a relational theory of copyright and how it might be engaged to reshape core elements of copyright doctrine in CRAIG, supra note 54, at 50-59.

84 See Jennifer Nedelsky, Law's Relations: A Relational Theory of Self, Autonomy, AND LAW 238 et seq. (2011). 
and stable across time and place, and cannot be eroded or overridden by democratic will or shifting social morals. ${ }^{85}$ Rights, in this sense, serve the protective function of guarding individuals, and safeguarding their entitlements, against the wants, interests and subjective values of others. The right to free speech, for example, is protected even as the speaker's views become less popular or more offensive to others over time. And as communication technologies evolve, that right extends not only to speech communicated in printed text or from the proverbial soapbox, but also to speech disseminated over new broadcasting media and in online spaces. ${ }^{86}$ Core to the liberal notion of the basic constitutional right is its capacity to transcend time and circumstance, thereby staking claim to something universal and unerring. Rights are thus reified as fixed entities. ${ }^{87}$

It is not surprising, then, that the author's claim to right — the proprietary right over the fruits of his creative labor - so often asserted or implicitly assumed in the context of our Western liberal copyright system, should perform a similar function of preserving and protecting an established entitlement in the face of changing circumstances and shifting social values ${ }^{88}$ The celebrated immutability of the right-claim is, however, precisely the problem for a rightsoriented copyright system trying to adapt to new technological challenges. Standing firm and unshifting in the face of technological change, the copyright claim-to-right refuses to bend and alter in response to technological evolution. It demands to be upheld and protected notwithstanding the many ways in which time and technology have come to challenge its purpose. This is what we have seen in the case law that invokes technological neutrality in its most minimalist form, as an interpretive tool to produce the strongest protection for the owner's right. The ingrained notion of rights as trumps supports the triumph of copyright over conflicting interests of both users and providers of new technologies, as well as, potentially, the broader public interest in creative innovation. The vision of a technologically neutral copyright law as I have described it — responsive to change, recalibrating rights and interests,

85 See Jeremy Waldron, A Rights-Based Critique of Constitutional Rights, 13 Oxford. J. Legal Stud. 18 (2013).

86 See William E. Lee, Books, Video Games, and Foul-Mouthed Hollywood Glitteratae: The Supreme Court and the Technology Neutral Interpretation of the First Amendment, 14 Colum. Sci. \& Tech. L. Rev. 295 (2013).

87 See Nedelsky, supra note 84, at 250; see also Duncan Kennedy, The Critique of Rights in Critical Legal Studies, in Left Legalism/Left CritiQue 178 (Wendy Brown \& Janet Halley eds., 2002).

88 See Justin Hughes, The Philosophy of Intellectual Property, 77 Geo. L.J. 287 (1988); see also Simon Stern, From Author's Right to Property Right, 62 U. TORONTO L.J. 29 (2012). 
extending or restraining itself as its purposes demand - is obstructed by the prevailing conception of rights on which our copyright system so often relies. ${ }^{89}$

The rhetoric of authors' rights casts copyright as an individual's natural entitlement, not amenable to pragmatic or principled alteration in the name of a broader public interest. ${ }^{90}$ Acknowledging, however, that claims of justice and fairness regarding artistic expression typically and increasingly do find their articulation in claims of rights (whether to property or free speech, copyright or users' rights), then perhaps energies are better spent debating "not whether but how the language of rights will be used." If If the invocation of the author's right stands in the way of expansive technological neutrality, perhaps technological neutrality needs a different understanding of the author's right.

A relational approach to rights analyzes legal rights in terms of the way they structure relationships. Pointing to the ever changing and continually contested nature of even basic rights such as property or equality, Jennifer Nedelsky regards rights as "a particular institutional and rhetorical means of expressing, contesting, and implementing ... values," where value means "any of the big abstractions used to articulate what a given society sees as essential to humanity or to the good life for its members." ${ }^{22}$ Included within such values might be, for example, liberty, autonomy, freedom of expression and, indeed, "scope for individual and/or collective artistic expression." 93 Since legal rights are the institutional implementation of societal values, the relational approach to resolving a rights dispute begins by asking how the law is structuring the relevant relations implicated in the dispute. It then proceeds to identify the values at stake; to ask what kinds of relationships would foster those values; and to consider how competing versions of the relevant right could structure those relationships in different ways.

Importantly, a relational approach to copyright recognizes and accepts that both the meaning of rights and the shared or common understanding of society's core values change over time. ${ }^{94}$ As Nedelsky explains, "[a] focus on relationship automatically turns one's attention to context and makes sense of the commonly held belief that there are some basic human values and that how we articulate and foster those values varies significantly over time and place. ${ }^{\circ 95}$ It must also be attentive to the reality that core values are

89 Sterk, supra note 56.

90 Cf. CRAIG, supra note 54, at 86.

91 Nedelsky, supra note 84, at 235.

92 Id. at 241.

93 Id.

94 Id. at 243.

$95 I d$. at 246. 
"disproportionately articulated and enforced by some powerful subset of the members of the society." ${ }^{\prime 6}$ The relational approach thus demands broad access to platforms of public deliberation about society's core values, and accepts that these values remain a site of constant contestation and possible transformation.

So what values might be said to be at stake in disputes about copyright and the new technological means by which it is exploited? The scope for individual creative expression is certainly implicated in debates about the claims to copyright protection in novel contexts. If, and to the extent that, protecting the owner's copyright will continue to provide a necessary incentive or reward for artistic creativity in the digital age, proprietary relations between authors and users may be said to advance that value. ${ }^{97}$ Other relationships and other social values will also be at play, however, and these may benefit from competing versions of rights that would structure relations in alternative, nonproprietary ways. ${ }^{98}$ Particular circumstances such as we have seen in the case law implicate other relations between, for example, corporate service providers and their customers, authors and publishers, creators and their audiences, users and their peers. As for the social values at stake, we might consider the progress of science or capacity for technological innovation, the scope for collective artistic expression or creative exchange, the freedom of expression, the value of cultural or creative community engagement, access to knowledge and information, education, equality, and so on.

As such, when we ask how the owner's copyright should be applied in a new technological context, we ought to ask how different available versions of the copyright interest could structure the relationships between affected parties differently (authors and users, consumers and service providers, etc.). We would then consider how structuring these relationships differently (shifting obligations, protecting privileges and freedoms, allowing competition, facilitating cooperation, etc.) would foster values such as supporting artistic creativity, furthering progress of the arts, protecting free expression, promoting a vibrant public domain, and so forth. As with the expansive approach to technological neutrality, the point is not to produce a particular answer for a specific case, but to ask the important questions that ought to be asked in

\section{Id. at 243.}

97 Cf. Wendy J. Gordon, Render Copyright unto Caesar: On Taking Incentives Seriously, 71 U. Chi. L. Rev. 75, 88-89 (2004); see also Robert P. Merges, Justifying Intellectual Property (2011).

98 Nedelsky's fourth step in the relational approach is "to determine how competing versions of a right would structure relations differently." NEDELSKY, supra note 84 , at 236. 
arriving at the best answer in the given context. As our lens pulls out to reveal relationships other than plaintiff versus defendant, and values other than simply protecting authors, there will be circumstances in which reinforcing proprietary relations, based on the power to exclude, will not suitably foster the social values at stake. In such cases, the legal dispute will not be appropriately resolved simply by recognizing and enforcing the owner's copyright in the new technological context (as the restrictive approach to technological neutrality might have us believe).

Copyright, it should be stressed, is not a primary value in itself, but a means by which to foster social values (in Nedelsky's terms, a "second-order value"): with respect to other rights and values it should therefore be treated as instrumental and not fundamental. ${ }^{99}$ Copyright ought to foster free expression, for example, and cannot be given primacy over it. In disputes over copyright, we should examine the context of the dispute, the social values represented and implemented through copyright, and then ask whether the extension of copyright, its limitation, or the recognition of a countervailing user's right, would best foster those values. As I see it, this line of inquiry closely mirrors the kind of contextual and dynamic approach to interpreting and applying copyright law that I have portrayed as essential to a substantively technologyneutral copyright system.

Thus, in Robertson, for example, the minority reasons described the relationship between freelance authors and publishers in the context of the larger public interest in archived newspapers as a resource, noting that the shared "interests of teachers, students, writers, reporters, and researchers" in using the materials were "hang[ing] in the balance between the competing rights of the two groups of creators in this case, the authors and the publishers." 100 These passages implicitly invoked the social values at stake in the dispute - education, pursuit of knowledge, access to information - revealing an awareness of how the authors' rights-claim, by restricting access and dissemination, might impede pursuit of those values. In $E S A$, the majority concerned itself with the relationship between consumers and distributors, invoking efficiency and competition as attendant social values, and refusing

$99 C f$. NedELSKY, supra note 84, at 255 (describing property as a "second-order value" that "should be treated as instrumental to both rights and values, not as a primary value or a fundamental right"). Notably, Nedelsky's reluctance to use property as the focal point of rights stems from the strong connection between property and boundaries, while her relational account rejects boundaries in favor of relationships. Id. at 130-34. Copyright as intellectual property suffers from the same focus on legally constructed boundaries.

100 Robertson v. Thomson Corp., [2006] S.C.C. 43 ๆ 70 (Can.). 
to construct a relationship between the collective society and distributors that would undermine these values. ${ }^{101}$ In $C B C$, Justice Abella's dissent invoked the value of efficiency and innovation, looking at the relationship between the public broadcaster, multiple collectives, and the creators of musical works. She attempted to interpret the reproduction right in a way that would structure the relationships to foster rather than punish efficiencies generated by technological innovation. ${ }^{102}$ While none of these judgments completely or consciously adopts a relational approach as such, an appreciation of affected relationships and their implications for the core social values that copyright reflect is apparent in the reasoning of all of the cases we have considered as examples of expansive technological neutrality, almost by definition. In these cases, the emphasis is not on individual rights and the enforcement of legal boundaries, but on the public purposes of the law, and the question of when - and subject to what limits - to structure the parties' relationship around the power to exclude and exploit.

As we saw in Section II.A., when copyright is applied to new technological contexts, invoking the author's right as the primary concern foretells a restrictive approach to technological neutrality: it is the perceived task of the decisionmaker simply to ensure that the right continues to be protected in novel circumstances. In cases where courts have expressly regarded authors' rights not in isolation but in relation to other rights and interests (balancing the owner's rights with users' rights, typically with reference to the public interest and/or the interests of the innovator/competitor or consumer/citizen), we have seen a more expansive and substantive concept of technological neutrality emerge. The connection between a more nuanced and relational understanding of copyright and a more expansive vision of technological neutrality seems clear. Expansive technological neutrality may require either extending or restaining copyright in new contexts in order to strike an appropriate balance, serving the purposes of copyright and fostering the social values that it represents. Copyright's limits (as with all reasonable limits to rights in the relational model) "cannot be specified in advance; they are, implicitly, open-ended and shifting, requiring judgment and debate." 103 This dynamic capacity to shift and change in response to changing circumstances — including the ability to limit rights and reshape legal relations — is vital to attaining technological neutrality in any real sense. A more relational approach to copyright can help build that

101 Entm't Software Ass'n (ESA) v. Soc'y of Composers, Authors and Music Publishers of Can., [2012] S.C.C. 34 甲ๆ 9, 11 (Can.).

102 Can. Broad. Corp. (CBC) v. SODRAC 2003, Inc., [2015] S.C.C. 57 甲ๆ 129, 169 (Can.).

103 Nedelsky, supra note 84, at 246. 
capacity. A rigid commitment to guarding the boundaries of authors' rights, on the other hand, forecloses such flexibility. Established rights can readily be imposed upon new technologies (it is not hard, after all, to find that a copy is a copy, a transmission is a communication, ownership is ownership), but they can just as readily upset the copyright balance and undermine the shared values that such rights ought to reflect.

\section{Conclusion}

From the time of Gutenberg to the digital era of Generation Z, the manner in which we create and exchange information has evolved in dramatic ways, at sporadic but frequently alarming rates, and in often unanticipated directions. Developments in our information and communication technologies have enabled more rapid, diverse and far-reaching information flows, reshaping our cultural landscape, changing patterns of human relationships, and shifting social values. If legal rights are to construct relationships that reflect social values, then these legal rights cannot be rigid and unmoving, but must shift and change as new technologies change us.

As one of the primary legal vehicles by which we regulate the controlled exchange of information resources, copyright law has become, rightly or wrongly, central to our evolving information system. As I have suggested, however, our copyright system lacks a consistent or concerted approach to responding to disruptive innovations in information technology. A firm adherence to protecting owners' rights (and safeguarding established proprietary and economic relationships) has frequently produced a restrictive understanding of technological neutrality: rights are simply protected and extended without sufficient regard to changes in the technological means of their exploitation. Others, committed to ensuring consistency of outcome in the application of copyright law across technologies, have made efforts to apply the law equally to functionally equivalent acts. This search for a more substantive equality amongst old and new technologies has been guided by a more robust version of technological neutrality, to be sure. To focus on the outcome of particular activities and the past application of existing doctrine, however, is still unduly narrow. In contrast, I have identified (and commended) a more purposive understanding of technological neutrality. This approach takes an expansive view of the activity at issue, situated in the new technological context, and asks how the law ought to apply if it is to further the purposes of the copyright system. The consistency sought is not consistency in the application of the law, but in the steady pursuit of its normative objectives recalibrating the copyright balance as conditions change. 
This version of technological neutrality necessitates an understanding of copyright and other legal rights at issue in the context of the relations that have generated the problem. It requires the decision-maker to ask how these rights will shape the relevant relations, and whether those relations will advance the social values at stake in our copyright system. It may be that other versions of copyright, users' rights or other rights and interests will produce new patterns of relationships that better serve these values.

Seen in this way, technological neutrality is not the state of being independent of and immune to technological flux; indeed, there is no law - and no person - that can claim such a state. Rather, it is a guiding principle, encouraging us to ask how the development and application of our laws can consistently foster the social values we consider essential, even in the face of such flux. 